\title{
Electrooxidation of Formic Acid Using Pt Nanoparticles Supported on Conducting Poly(vinylferrocene) Polymer Support
}

\author{
Poli(vinilferrosen) İletken Polimer Destekli Pt Nanopartikülleri \\ Kullanarak Formik Asitin Elektroyükseltgenmesi
}

\author{
Research Article
}

Mutlu Sönmez Çelebi ${ }^{*}$ and Kadir Pekmez ${ }^{2}$

'Ordu University, Faculty of Science and Arts, Department of Chemistry, Ordu, Turkey. ${ }^{2}$ Hacettepe University, Faculty of Science, Department of Chemistry, Ankara, Turkey.

\section{A B S TR AC T}

$\mathrm{M}$ ethanol as a fuel has some disadvantages such as toxicity and low electrocatalytic oxidation rate, therefore, alternative liquid fuels are of interest for fuel cell applications. Formic acid has been considered as an alternative which fulfilled the requirements such as ease of transportation and handling and high theoretical open circuit voltage. Platinum supported on poly(vinylferrocenium) (Pt/PVF) is a promising catalyst for use in direct formic acid fuel cells. This work deals with electrooxidation of formic acid on Pt/PVF catalyst system and comparison of methanol and formic acid. According to the scanning electron microscopy (SEM) images, Pt particles are well dispersed over the polymer support. The Pt/PVF catalyst displays enhanced catalytic activity towards formic acid oxidation. When compared with methanol electrooxidation at the identical conditions, better results are achieved for formic acid oxidation.

\section{Key Words}

Poly(vinylferrocene), Pt nanoparticles, formic acid, fuel cell.

\section{öz}

\begin{abstract}
Vakıt olarak metanolün toksisite ve düşük elektrokatalitik yükseltgenme hızı gibi bazı dezavantajları olduğu için yakıt pili uygulamalarında alternatif yakıtlar ilgi çekmektedir. Diğer taraftan, taşıma ve kullanım kolaylığının yanı sıra yüksek teorik açık devre potansiyeli gibi özellikleriyle dikkat çeken formik asit metanole alternatif olarak ortaya çıkmaktadır. Poli(vinilferrosen) destekli platin (Pt/PVF) doğrudan formik asit yakıt hücrelerinde kullanım için gelecek vadeden bir katalizördür. Bu çalışmada Pt/PVF katalizör sistemiyle formik asitin elektroyükseltgenmesi ile metanol ve formik asitin karşılaştırılması yer almaktadır. Taramalı elektron mikroskobu görüntülerine göre, Pt tanecikleri polimer destek üzerinde düzgün dağılmıştır. Pt/PVF katalizörü formik asit yükseltgenmesi için yüksek katalitik aktivite göstermiştir. Aynı koşullarda metanolün elektroyükseltgenmesiyle karşılaştırıldığında, formik asit için daha iyi sonuçlar elde edilmiştir.
\end{abstract}

\section{Anahtar Kelimeler}

Poli(vinilferrosen), Pt nanopartikülleri, formik asit, yakıt pili.

Article History: Received: Mar 15, 2017; Revised: Jul 25, 2017; Accepted: Oct 15, 2017; Available Online: Dec 25, 2017. DOI: $10.15671 / \mathrm{HJBC} .2018 .175$

Correspondence to: M.S. Çelebi, Ordu University, Faculty of Science and Arts, Department of Chemistry, Ordu, Turkey. 


\section{INTRODUCTION}

Decently, direct fuel cells which use liquid fuels attract much more attention than the hydrogen based ones mainly because of the high cost of miniaturized hydrogen containers and the potential dangers in the transport and use of hydrogen. Among various liquid fuels, methanol has been extensively investigated due to its impressive energy density. However, because of its toxicity, low electrocatalytic oxidation rate and limited compatibility with $\mathrm{Nafion}^{\circledR}$ membranes (hence use of low methanol concentrations), alternatives to direct methanol fuel cell (DMFC) have been investigated [1,2]. Direct formic acid fuel cell (DFAFC) has been the focus of such investigations because of its advantages over DMFC such as higher theoretical open circuit potential and lower fuel crossover [3-5]. Formic acid is a non-toxic liquid which is inflammable, thus its storage and transportation is relatively easy and safe. It is well known from the previous studies that Pt-based catalysts show good catalytic activity towards electrooxidation of formic acid [1,5-9].

Incorporation of metal nanoparticles onto suitable supporting materials greatly enhances the catalytic properties of the metals allowing the generation of metal nanoparticles with a controlled size and size distribution [10]. Many supporting materials were investigated for metal nanoparticles such as conducting polymers [1114], carbon nanotubes [15-17], graphene [18-20] and various hybrid materials [21-23].

Poly(vinylferrocene) (PVF) is a conducting polymer featuring redox properties which is commonly used as a favorable agent for preparing modified electrodes with desired surface properties [24]. Upon the advantages of using PVF for modification, simple electrochemistry with a reversible one-electron process, high stability, and ease of deposition of thin films using a variety of methods are the most outstanding ones. PVF oxidizes from methylene chloride to give the less soluble ferrocenium form of the polymer $(P V F+)$ precipitating onto the electrode surface. Owing to these characteristics, PVF modified electrodes have been widely applied to many applications such as electroanalysis [25-27], biosensors [28-
30] and preparation of polymer supported metal catalysts $[11,12,31]$.

In this work, electrooxidation of formic acid was studied on Pt nanoparticles supported onto PVF conducting polymer matrix. Structural characterization of the Pt/PVF catalyst system was evaluated by scanning electron microscopy (SEM) technique. Catalytic activity of the electrocatalyst was examined via cyclic voltammetry experiments performed in formic acid solutions in acidic medium. The system was tested using a homemade single DFAFC configuration in terms of fuel cell performance and open circuit voltage (OCV). Cyclic voltammograms (CVs) and OCV values were also compared with methanol electrooxidation at identical conditions.

\section{MATERIALS and METHODS}

\section{Reagents and Instruments}

PVF was prepared by chemical polymerization of vinylferrocene at $70^{\circ} \mathrm{C}$ for $24 \mathrm{~h}$ using 2,2 -asobis(2-methylpropionitrile) (AIBN) as the initiator [32]. Vinylferrocene and tetra-n-butyl ammonium perchlorate (TBAP) was purchased from SigmaAldrich. AIBN was obtained from Alfa. Methylene chloride (HPLC grade), formic acid, $\mathrm{H}_{2} \mathrm{SO}_{4}$ and $\mathrm{K}_{2} \mathrm{PtCl}_{4}$ were obtained from Merck and used asreceived. Hydrazine solution was prepared using hydrazinium sulfate $\left(\mathrm{NH}_{2} \cdot \mathrm{NH}_{2} \cdot \mathrm{H}_{2} \mathrm{SO}_{4^{\prime}}\right.$ Merck). All solutions were deoxygenated by bubbling pure nitrogen gas (BOS) prior to use in the electrochemical experiments.

The potential-controlled coulometric and cyclic voltammetric studies were carried out with $\mathrm{CH}$ Instruments System, Model 608B. The catalyst system was examined using a Gemini scanning electron microscope equipped with Leo 32 Supra 35VP field emission scanning system.

\section{Electrodes}

In electrochemical experiments, a Pt disc electrode $\left(A=7.85 \times 10^{-3} \mathrm{~cm}^{2}\right)$ was used as the working electrode. Before each experiment, the working electrode was polished with alumina $(5.0 \mu \mathrm{m})$, then rinsed with triple distilled water, cleaned in ultrasonic bath and dried. During the electrodeposition of the polymer film onto 


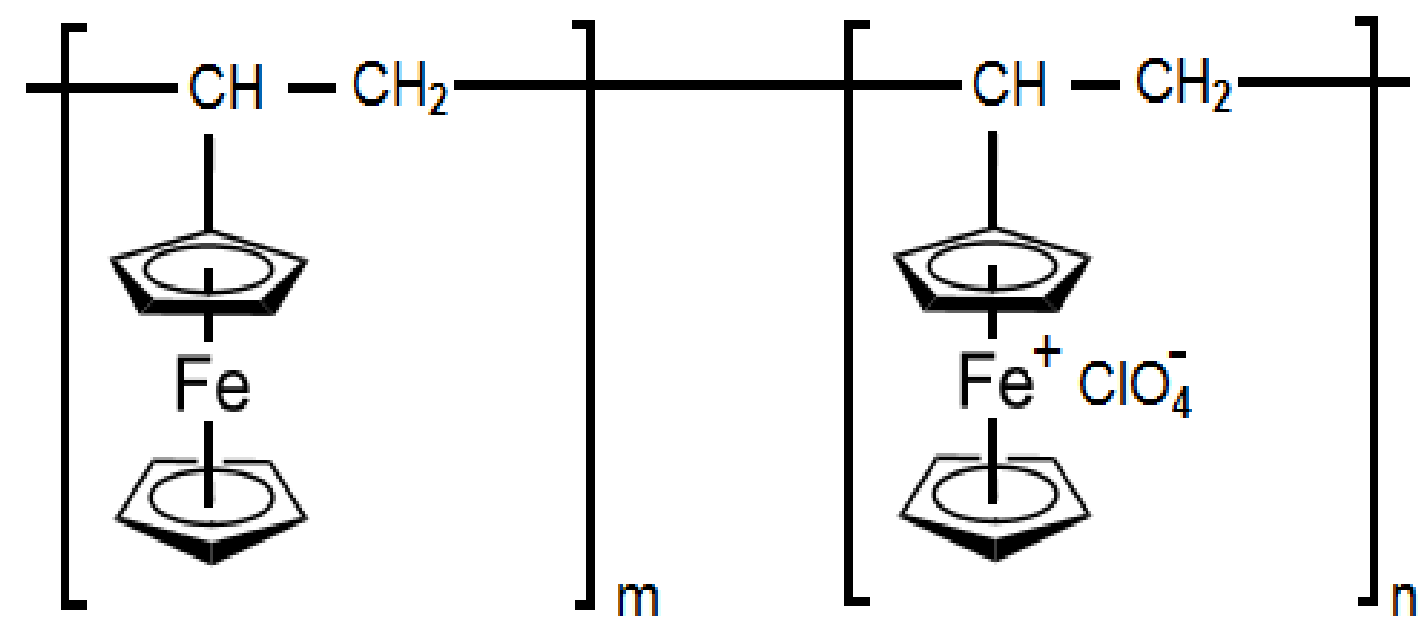

Figure 1. Electrochemically doped PVF.

the working electrode, a $\mathrm{Ag} / \mathrm{AgCl}$ electrode was used as the reference electrode. This electrode was prepared by anodic electrolysis of a silver electrode in $0.1 \mathrm{M} \mathrm{HCl}$ solution for $3 \mathrm{~h}$ at $+2.1 \mathrm{~V}$ with a current density of $2 \mathrm{~mA} \mathrm{~cm}^{-2}$. The electrode was immersed in a separate compartment containing methylene chloride/0.1 M TBAP solution with a saturated amount of $\mathrm{AgCl}$. In methylene chloride medium, a Pt wire in separate compartment containing methylene chloride/0.1 M TBAP solution was used as the counter electrode. In aqueous medium, a saturated calomel electrode (SCE) was used as the reference electrode and a Pt wire with a surface area of $2 \mathrm{~cm}^{2}$ in spiral form was used as the counter electrode.

\section{Preparation of Pt/PVF Catalyst}

Pt/PVF electrocatalyst was prepared according to the procedure described in our previous work [11]. The polymer was electrodeposited onto the electrode surface by the electrooxidation of $1.0 \mathrm{mg} \mathrm{mL}^{-1} \mathrm{PVF}$ solution in methylene chloride containing $0.1 \mathrm{M}$ TBAP at $+0.7 \mathrm{~V}$ vs. $\mathrm{Ag} / \mathrm{AgCl}$. The thicknesses of $\mathrm{PVF}+\mathrm{ClO}_{4}^{-}$films were controlled by the charge passed during the electroprecipitation. A charge of $1 \times 10^{-3} \mathrm{C}$ corresponded to $1.32 \times 10^{-6}$ mol of the oxidized PVF per $\mathrm{cm}^{2}$ (dry thickness of $300 \mu \mathrm{m}$, which corresponds to about $3 \times 10^{5}$ layers) [33]. The resulting film is in a porous structure containing $\mathrm{ClO}_{4}^{-}$ions as the counter ion, ferrocene and ferrocenium groups (Figure 1).
Pt complex $\left(\mathrm{PtCl}_{4}{ }^{2-}\right)$ anions were incorporated into the polymer matrix using cyclic voltammetric scans between potentials -0.85 and $+1.15 \mathrm{~V}$ vs SCE via counter ion exchange process in aqueous $2 \mathrm{mM}$ $\mathrm{K}_{2} \mathrm{PtCl}_{4}$ solution without supporting electrolyte. Polymer-coated electrode containing Pt complex $\left(\mathrm{PtCl}_{4}{ }^{2-}\right)$ as the counter ion was immersed in 0.1 $\mathrm{M}$ hydrazine solution stirred continuously at open circuit in order to reduce the Pt complexes completely to metallic Pt nanoparticles.

\section{Single Fuel Cell Test}

Nafion ${ }^{\circledR}$ membrane (NE 450, Aldrich) was used in the DFAFC construction. The anode was Pt/PVF catalyst system prepared using Pt foil electrode $(1 \mathrm{~cm} \times 1 \mathrm{~cm})$. Pt black-coated Pt electrode was used as the cathode material. $6 \mathrm{M} \mathrm{HCOOH}$ solution containing $0.5 \mathrm{M} \mathrm{H}_{2} \mathrm{SO}_{4}$ was used as the fuel and $0.5 \mathrm{M} \mathrm{H}_{2} \mathrm{SO}_{4}$ solution which was saturated by pure $\mathrm{O}_{2}$ gas was used as the oxidant. The system was tested with a homemade single cell with a working area of $1 \mathrm{~cm}^{2}$. The cell performance was tested at ambient temperature and atmospheric pressure.

\section{RESULTS and DISCUSSION}

In order to observe the physical structure of the catalyst system, Pt/PVF catalyst was prepared on a piece of $\mathrm{Pt}$ foil $(3 \mathrm{~mm} \times 3 \mathrm{~mm}$ ) and monitored by SEM. The obtained SEM images revealed well dispersion of Pt particles over highly porous 

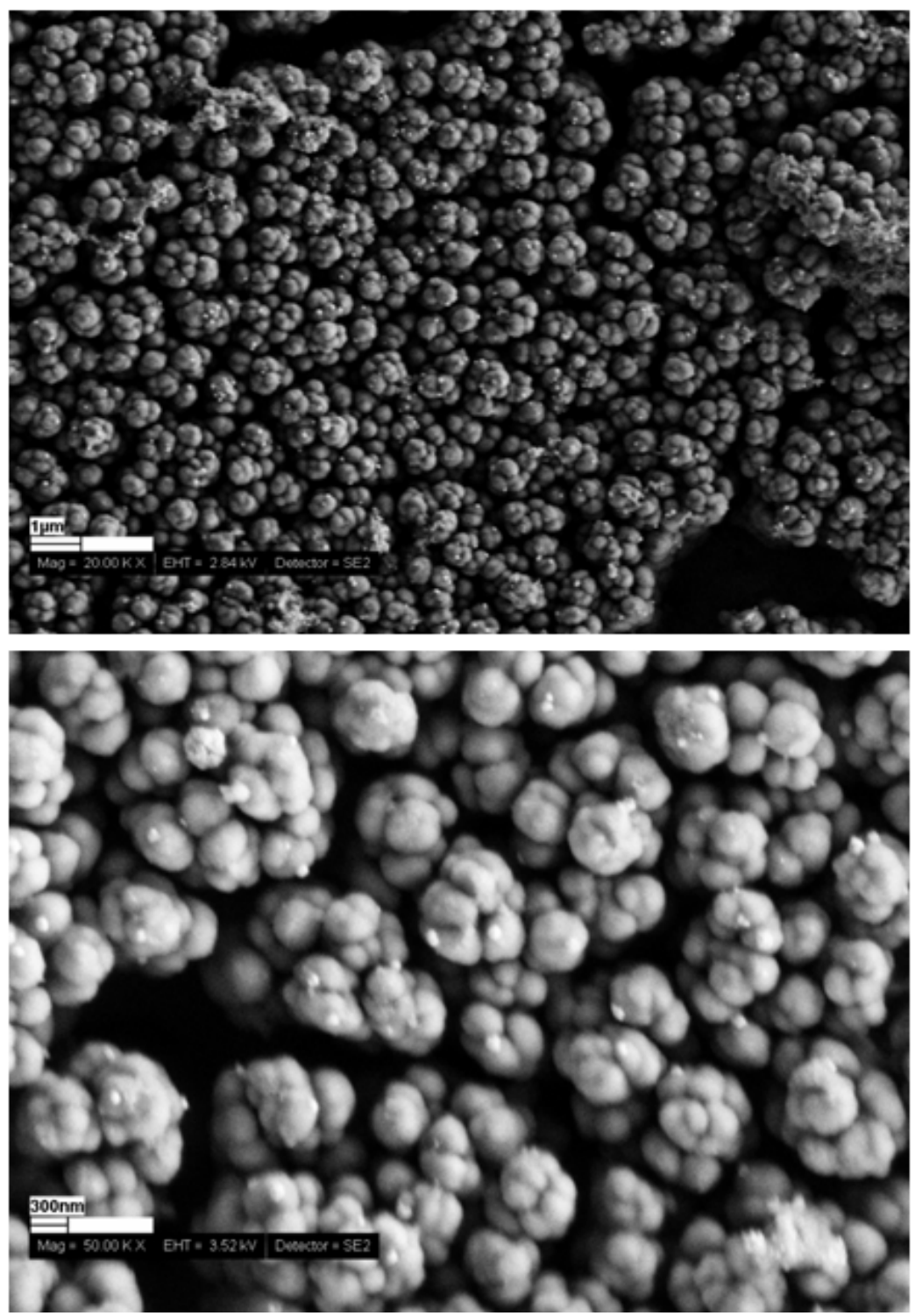

Figure 2. SEM images of Pt/PVF catalyst at two different magnifications.

polymer matrix with diameters at the nanoscale around 50-60 nm (Figure 2).

We calculated the maximum theoretical amount of $\mathrm{Pt}$ loaded to the catalyst system taking into account the precipitated PVF per $\mathrm{cm}^{2}$ as $104 \mu \mathrm{g} \mathrm{cm}^{-2}$ [33]. This amount of Pt loading itself is better than similar Pt nanoparticles-based catalysts for formic acid oxidation [9,34]. In fact, considering the actual ratio of Fe:Pt (hence PVF:Pt) as 10:1 based on our previous work [11], we obtained a Pt loading as low as $10 \mu \mathrm{g} \mathrm{cm}^{-2}$. This Pt loading can be regarded as a comparable catalyst loading indicating a reasonable noble metal consumption [35-37].
According to the most-accepted mechanism of formic acid oxidation, the reaction occurs via dual pathway mechanism [1,38-40]. In pathway 1 , direct oxidation of formic acid occurs via a dehydrogenation step without any intermediate. However, in the second pathway, formation of adsorbed carbon monoxide as a reaction intermediate occurs by dehydration followed by formation of carbon dioxide as the end product. For formic acid fuel cell applications, dehydrogenation is the preferable reaction pathway in order to avoid poisoning of the catalyst. CVs of uncoated $\mathrm{Pt}$ disc electrode and Pt/PVF catalyst in $0.5 \mathrm{M}$ $\mathrm{HCOOH}$ solution containing $0.5 \mathrm{M} \mathrm{H}_{2} \mathrm{SO}_{4}$ are 


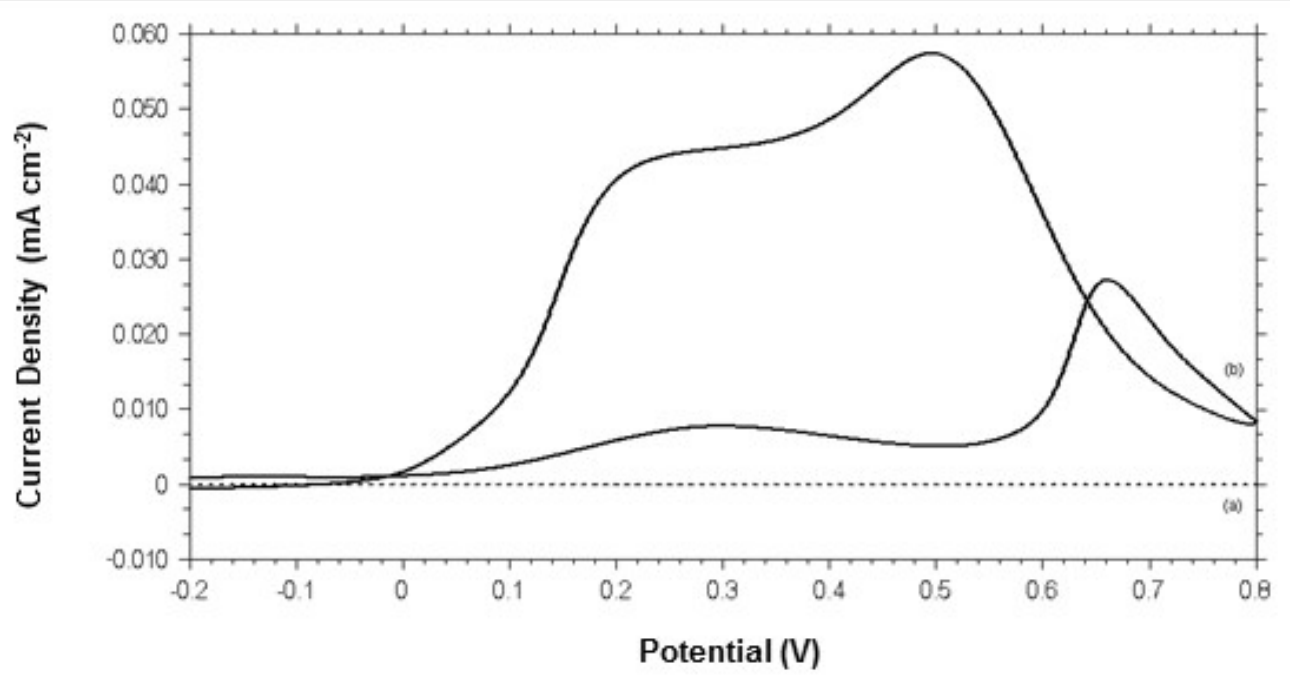

Figure 3. CVs recorded with (a) uncoated Pt disc electrode and (b) Pt/PVF coated Pt disc electrode in $0.5 \mathrm{M} \mathrm{HCOOH}+$ $0.5 \mathrm{M} \mathrm{H}_{2} \mathrm{SO}_{4}$ solution, scan rate $=50 \mathrm{mV} \mathrm{s}^{-1}$.

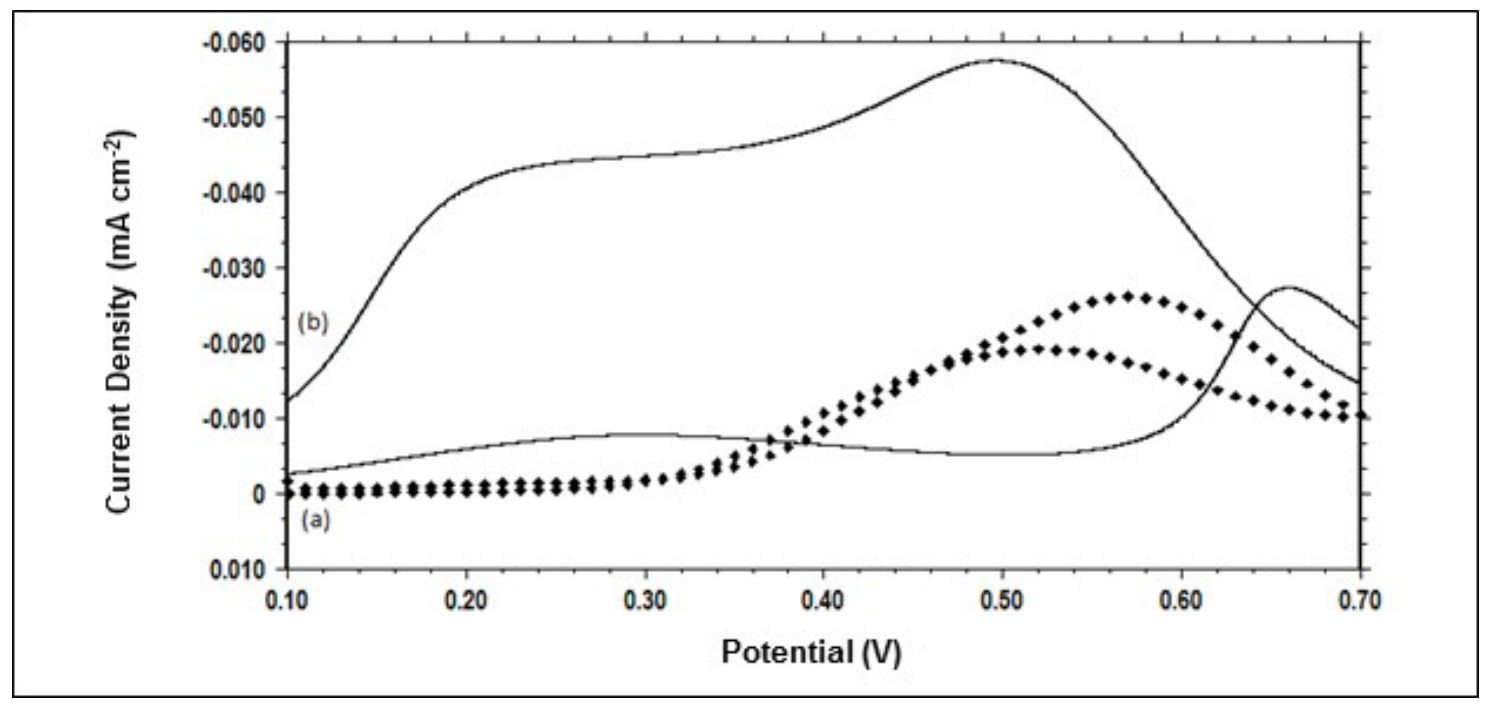

Figure 4. $\mathrm{CCVs}$ recorded with $\mathrm{Pt} / \mathrm{PVF}$ coated $\mathrm{Pt}$ disc electrode in (a) $0.5 \mathrm{M} \mathrm{CH}_{3} \mathrm{OH}+0.5 \mathrm{M} \mathrm{H}_{2} \mathrm{SO}_{4}$ (scan rate: $50 \mathrm{mV}$ $\mathrm{s}^{-1}$ ) and (b) $0.5 \mathrm{M} \mathrm{HCOOH}+0.5 \mathrm{M} \mathrm{H}_{2} \mathrm{SO}_{4}$ (scan rate: $5 \mathrm{mV} \mathrm{s}^{-1}$ ).

given in Figure 3 (vs. SCE). The shape of the CV of $\mathrm{HCOOH}$ on Pt nanoparticles is consistent with similar studies $[9,41,42]$. As shown, bulk Pt has negligible catalytic activity towards formic acid oxidation. For Pt/PVF catalyst, two peaks were observed in the forward scan. The first peak around $0.30 \mathrm{~V}$ results from direct oxidation of formic acid while the second peak at $0.66 \mathrm{~V}$ refers to the indirect path. According to these observations, oxidation of formic acid occurs via both pathways with Pt/PVF catalyst.

We also compared the intensity of formic acid oxidation peak with methanol oxidation peak at the same concentration (Figure 4). It was observed that formic acid oxidation peak current was superior to that of methanol oxidation when recorded with identical Pt/PVF catalyst, which indicates advantage of formic acid over methanol for fuel cell applications.

In order to test the fuel cell performance of the Pt/PVF catalyst, we constructed a homemade DFAFC with a working area of $1 \mathrm{~cm}^{2}$ in batch mode. When the anode was fed with $6 \mathrm{M}$ $\mathrm{HCOOH}$ containing $0.5 \mathrm{M} \mathrm{H}_{2} \mathrm{SO}_{4}$, an OCV of 724 $\mathrm{mV}$ was obtained with a maximum power density of $1.32 \mathrm{~mW} \mathrm{~cm}^{-2}$ at $4.4 \mathrm{~mA} \mathrm{~cm}^{-2}$. Graphs of current 


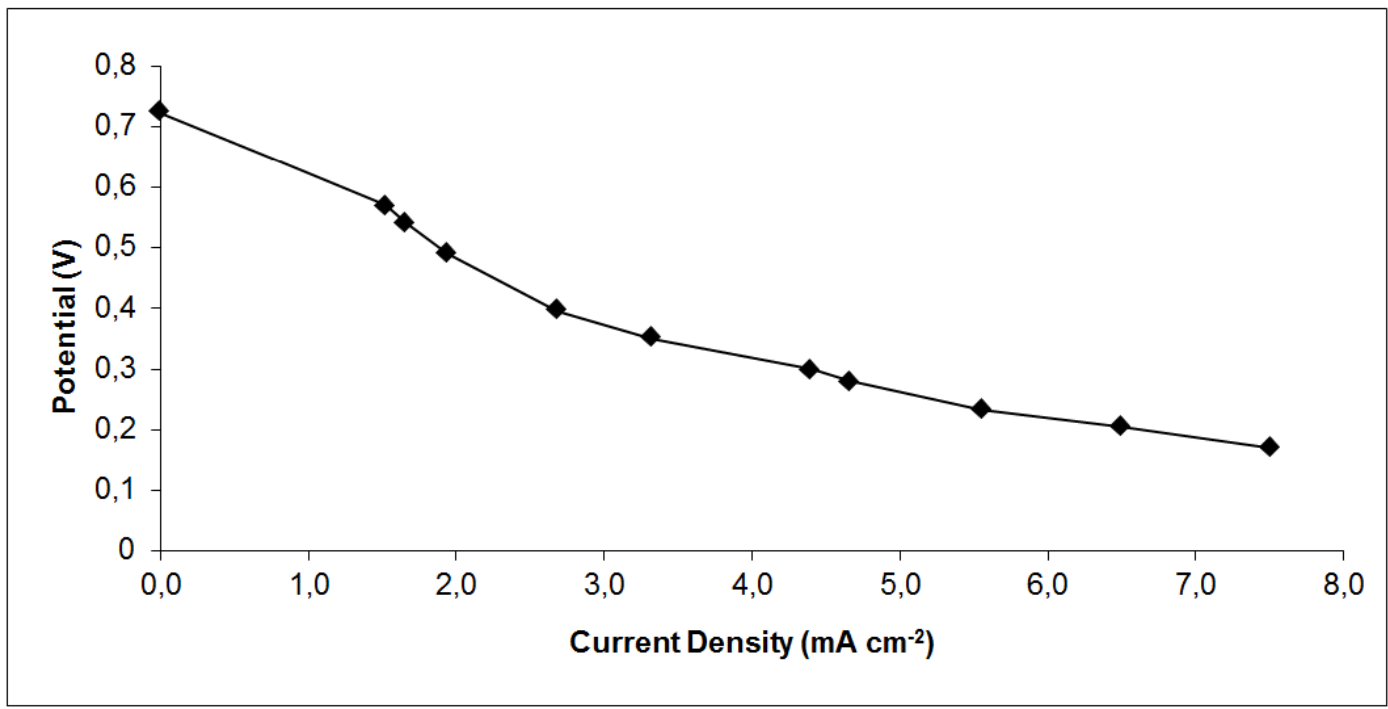

Figure 5. Current density/potential diagram for single DFAFC using Pt/PVF catalyst as anode and Pt black as cathode at ambient temperature and atmospheric pressure in $6 \mathrm{M} \mathrm{HCOOH}$.

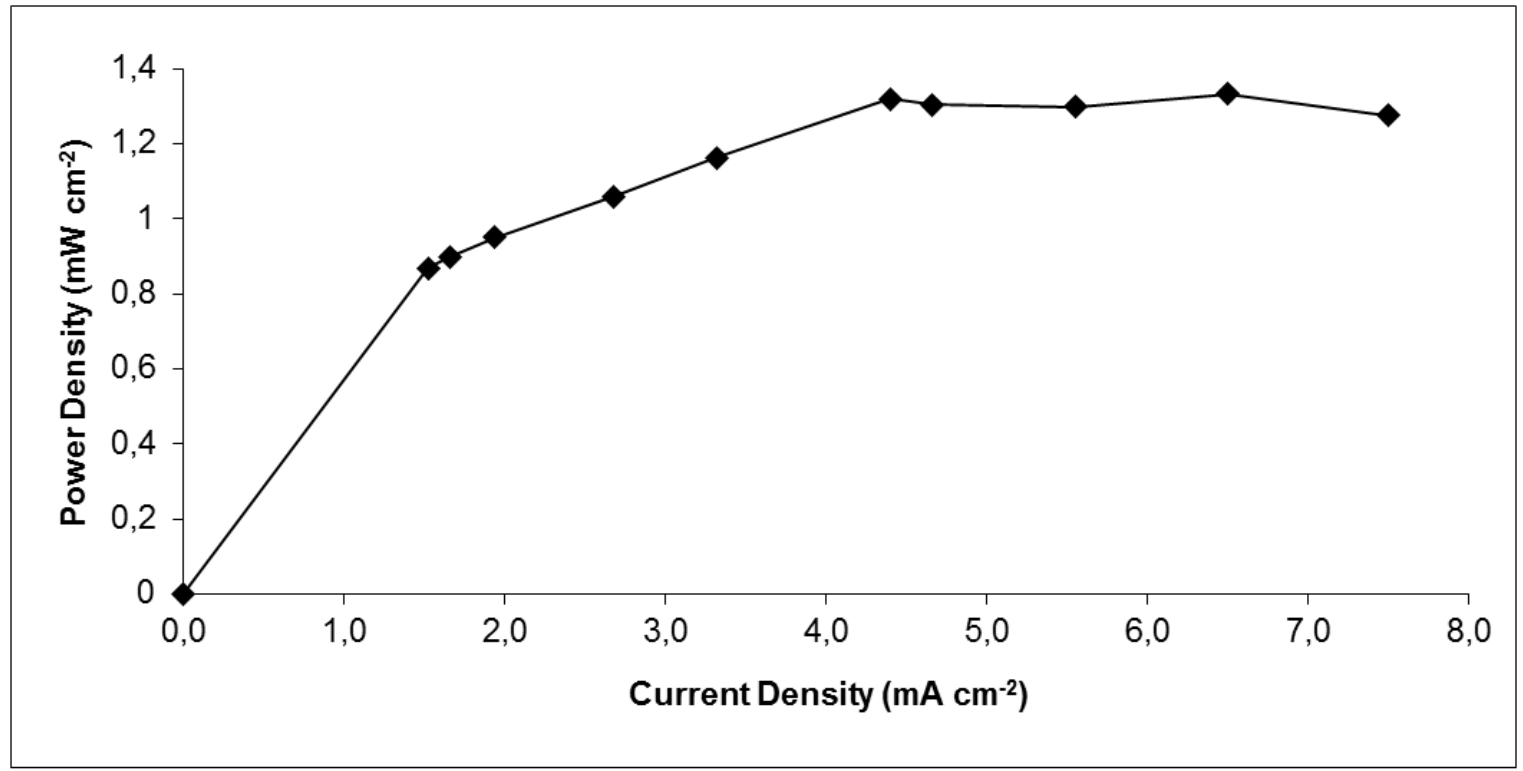

Figure 6. Current density/power density diagram for single DFAFC using Pt/PVF catalyst as anode and Pt black as cathode at ambient temperature and atmospheric pressure in $6 \mathrm{M} \mathrm{HCOOH}$.

density versus potential and power density values are given in Figures 5 and 6 respectively.

Finally we compared fuel cell performances in DMFC [11] and DFAFC modes at identical conditions. According to the results presented in Table 1, using formic acid instead of methanol as fuel resulted with higher OCV and power density values at the same conditions.

\section{CONCLUSIONS}

Pt/PVF catalyst system was used for electrooxidation of formic acid in acidic medium. It was observed that the catalyst system with a low Pt loading showed enhanced catalytic activity towards formic acid oxidation. In order to reveal the advantage of formic acid over methanol as a fuel, CVs and fuel cell test results were compared 
Table 1. Comparison of DMFC and DFAFC at the same conditions (2M fuel) with Pt/PVF anode.

\begin{tabular}{ccc}
\hline & DMFC11 & DFAFC \\
\hline Open Circuit Voltage & $680 \mathrm{mV}$ & $715 \mathrm{mV}$ \\
\hline Max. Power Density & $0.31 \mathrm{~mW} \mathrm{~cm}^{-2}$ at $0.63 \mathrm{~mA} \mathrm{~cm}^{-2}$ & $0.435 \mathrm{~mW} \mathrm{~cm}^{-2}$ at $1.5 \mathrm{~mA} \mathrm{~cm}^{-2}$ \\
\hline
\end{tabular}

at identical conditions. As expected, higher oxidation peak current values were obtained for formic acid with respect to methanol. Consistent with this result, a higher OCV was also obtained for DFAFC than that of DMFC.

\section{References}

1. X. Yu, P.G. Pickup, Recent advances in direct formic acid fuel cells (DFAFC), J. Power Sources, 182 (2008) 124-132.

2. B. Liu, H.Y. Li, L. Die, XH. Zhang, Z. Fan, J.H. Chen, Carbon nanotubes supported PtPd hollow nanospheres for formic acid electrooxidation, J. Power Sources, 186 (2009) 62-66.

3. S. Wang, N. Kristian, S. Jiang, X. Wang, Controlled deposition of Pt on Au nanorods and their catalytic activity towards formic acid oxidation, Electrochem. Commun., 10 (2008) 961-964.

4. X. Wang, Y. Tang, Y. Gao, T. Lu, Carbon-supported PdIr catalyst as anodic catalyst in direct formic acid fuel cell, J. Power Sources, 175 (2008) 784-788.

5. Y.N. Wu, S.J. Liao, Y.L. Su, J.H. Zeng, D. Dang, Enhancement of anodic oxidation of formic acid on palladium decorated Pt/C catalyst, J. Power Sources, 195 (2010) 6459-6462.

6. V. Selvaraj, M. Alagar, I. Hamerton, Nanocatalysts impregnated polythiophene electrodes for the electrooxidation of formic acid, Appl. Catal. B-Environ., 73 (2007) 172-179.

7. Z. Liu, L. Hong, M.P. Tham, T.H. Lim, H. Jiang, Nanostructured $\mathrm{Pt} / \mathrm{C}$ and $\mathrm{Pd} / \mathrm{C}$ catalysts for direct formic acid fuel cells, J. Power Sources, 161 (2006) 831-835.

8. W. Zhou, C. Wang, J. Xu, Y. Du, P. Yang, High efficient electrooxidation of formic acid at a novel Pt-indole composite catalyst prepared by electrochemical selfassembly, J. Power Sources, 196 (2011) 1118-1122.

9. J. Shi, Z.Y. Zhang, Y.Q. Hu, Y.X. Hua, Incorporation of 4-aminobenzene functionalized multi-walled carbon nanotubes in polyaniline for application in formic acid electrooxidation, J. Appl. Polym. Sci., 118 (2010) 1815-1820.

10. E. Antolini, Carbon supports for low-temperature fuel cell catalysts, Appl. Catal. B-Environ., 88 (2009) 1-24.

11. M. Sönmez Çelebi, K. Pekmez, H. Özyörük, A. Yıldız, Preparation and physical/electrochemical characterization of $\mathrm{Pt} /$ poly(vinylferrocenium) electrocatalyst for methanol oxidation, J. Power Sources, 183 (2008) 8-13.
12. M. Sönmez Çelebi, K. Pekmez, H. Özyörük, A. Yıldız, Electrochemical synthesis of $\mathrm{Pd}$ particles on poly(vinylferrocenium), Catal. Commun., 9 (2008) 2175-2178.

13. W. Zhou, J. Xu, Y. Du, P. Yang, Polycarbazole as an efficient promoter for electrocatalytic oxidation of formic acid on Pt and Pt-Ru nanoparticles, Int. J. Hydrogen Energy, 36 (2011) 1903-1912.

14. G. Zhang, B. Ding, L. Wu, L. He, B. Ni, J. Lu, Possible tuning fabrication of nanoplatinum particles with the conducting copolymer films and their behavior toward the electrooxidation of methanol, J. Appl. Polym. Sci., 129 (2013) 1593-1606.

15. J.J. Wang, G.P. Yin, J. Zhang, Z.B. Wang, Y.Z. Gao, High utilization platinum deposition on single-walled carbon nanotubes as catalysts for direct methanol fuel cell, Electrochim. Acta, 52 (2007) 7042-7050.

16. H. Su, B. Zhang, L. Chen, Preparation and Characterization of Platinum Supported on Carbon Nanotubes with Different Tube Diameter for Cathode Catalysts of Proton Exchange Membrane Fuel Cells, J. Mater. Sci. Technol., 26 (2010) 529-534.

17. A.Orfanidi, M.K. Daletou, S.G. Nephytides, Preparation and characterization of Pt on modified multi-wall carbon nanotubes to be used as electrocatalysts for high temperature fuel cell applications, Appl. Catal. B-Environ., 106 (2011) 379-389.

18. Y. Xin, J.G. Liu, Y. Zhou, W. Liu, J. Gao, Y. Xie, Y. Yin, Z. Zou, Preparation and characterization of Pt supported on graphene with enhanced electrocatalytic activity in fuel cell, J. Power Sources, 196 (2011) 1012-1018.

19. S. Park, Y. Shao, H. Wan, P.C. Rieke, V.V. Viswanathan, S.A. Towne, L.V. Saraf, J. Liu, Y. Lin, Y. Wang, Design of graphene sheets-supported Pt catalyst layer in PEM fuel cells, Electrochem. Commun., 13 (2011) 258261.

20. J.N. Tiwari, R.N. Tiwari, G. Singh, K.S. Kim, Recent progress in the development of anode and cathode catalysts for direct methanol fuel cells, Nano Energy, 2 (2013) 553-578.

21. W. Zhou, Y. Du, H. Zhang, J. Xu, P. Yang, High efficient electrocatalytic oxidation of formic acid on Pt/ polyindoles composite catalysts, Electrochim. Acta, 55 (2010) 2911-2917.

22. Z. Zhang, Y. Huang, J. Ge, C. Liu, T. Lu, W. Xing, $\mathrm{WO}_{3} / \mathrm{C}$ hybrid material as a highly active catalyst support for formic acid electrooxidation, Electrochem. Commun., 10 (2008) 1113-1116.

23. M. Lei, T.Z. Yang, W.J. Wang, K. Huang, R. Zhang, X.L. Fu, H.J. Yang, Y.G. Wang, W.H. Tang, Selfassembled mesoporous carbon sensitized with ceria nanoparticles as durable catalyst support for PEM fuel cell, Int. J. Hydrogen Energy, 38 (2013) 205-211. 
24. A. Glidle, J. Cooper, A.R. Hillman, L. Bailey, A. Jackson, J.R.P. Webster, Redox controlled partition and spatial distribution of solvent and salt in electroactive polyvinylferrocene films, Langmuir, 19 (2003) 77467753.

25. F. Kuralay, H. Özyörük, A. Yıldız, Inhibitive determination of $\mathrm{Hg}_{2}+$ ion by an amperometric urea biosensor using poly (vinylferrocenium) film, Enzyme Microb. Tech., 40 (2007) 1156-1159.

26. M. Sönmez Çelebi, H. Özyörük, A. Yıldız, S. Abacı, Determination of $\mathrm{Hg}_{2}+$ on poly (vinylferrocenium) $(\mathrm{PVF}+)$-modified platinum electrode, Talanta, 78 (2009) 405-409.

27. M. Kavanoz, N.Ö. Pekmez, Poly (vinylferrocenium) perchlorate-polyaniline composite film-coated electrode for amperometric determination of hydroquinone, J. Solid State Electrochem., 16 (2012) 1175-1186.

28. F. Kuralay, H. Özyörük, A. Yıldız, Potentiometric enzyme electrode for urea determination using immobilized urease in poly (vinylferrocenium) film, Sensor. Actuat. B-Chem., 109 (2005) 194-199.

29. F. Kuralay, H. Özyörük, A. Yıldız, Amperometric enzyme electrode for urea determination using immobilized urease in poly (vinylferrocenium) film Sensor. Actuat. B-Chem., 114 (2006) 500-506.

30. B.C. Özer, H. Özyörük, S.S. Çelebi, A. Yıldız, Amperometric enzyme electrode for free cholesterol determination prepared with cholesterol oxidase immobilized in poly (vinylferrocenium) film, Enzyme Microb. Tech., 40 (2007) 262-265.

31. E. Akgül, A. Gülce, H. Gülce, Electrocatalytic oxidation of methanol on poly(vinylferrocene) modified $\mathrm{Pt}$ electrode, J. Electroanal. Chem., 668 (2012) 73-82.

32. C. Aso, T. Kunitake, T. Nakashima, Cationic polymerization and copolymerization of vinylferrocene, Macromol. Chem., 124 (1969) 232-239.

33. J.J. Peerce, A.J. Bard, Polymer films on electrodes: Part II. Film structure and mechanism of electron transfer with electrodeposited poly (vinylferrocene), J. Electroanal. Chem., 112 (1980) 97-115.
34. C.T. Hsieh, W.Y. Chen, D.Y. Tzou, A.K. Roy, H.T. Hsiao, Atomic layer deposition of $\mathrm{Pt}$ nanocatalysts on graphene oxide nanosheets for electro-oxidation of formic acid, Int. J. Hydrogen Energy, 37 (2012) 1783717843.

35. J.B. Xu, T.S. Zhao, Z.X. Liang, Carbon supported platinum-gold alloy catalyst for direct formic acid fuel cells, J. Power Sources, 185 (2008) 857-861.

36. B. Fang, M. Kim, J.S. Yu, Hollow core/mesoporous shell carbon as a highly efficient catalyst support in direct formic acid fuel cell, Appl. Catal. B-Environ., 84 (2008) 100-105.

37. X.M. Wang, Y.Y. Xia, FexC-C hybrid material as a support for Pt anode catalyst in direct formic acid fuel cell, Electrochem. Commun., 11 (2009) 28-30.

38. W. Zhou, C. Wang, J. Xu, Y. Du, P. Yang, High efficient electrooxidation of formic acid at a novel Pt-indole composite catalyst prepared by electrochemical selfassembly, J. Power Sources, 196 (2011) 1118-1122.

39. V. Selvaraj, M. Alagar, K. Sathish Kumar, Synthesis and characterization of metal nanoparticles-decorated PPY-CNT composite and their electrocatalytic oxidation of formic acid and formaldehyde for fuel cell applications, Appl. Catal. B-Environ., 75 (2007) 129-138.

40. J. Masud, M.T. Alam, M.R. Miah, T. Okajima, T. Ohsaka, Enhanced electrooxidation of formic acid at $\mathrm{Ta}_{2} \mathrm{O}_{5}$ modified Pt electrode, Electrochem. Commun., 13 (2011) 86-89.

41. X. Zhong, Z. Wang, Y. Huang, Y. Yu, Q. Feng, Q. $\mathrm{Li}$, Fabrication of $\mathrm{Pt}$ nanoparticles on ethylene diamine functionalized graphene for formic acid electrooxidation, Int. J. Hydrogen Energy, 39 (2014) 15920-15927.

42. H. Zhao, Y. Wang, Q. Tang, L. Wang, H. Zhang, C. Quan, T. Qi, Pt catalyst supported on titanium suboxide for formic acid electrooxidation reaction, Int. J. Hydrogen Energy, 39 (2014) 9621-9627. 